\title{
Effect of Weather Parameter on the Population of Pink Bollworm, Pectinophora gossypiella (Saunders) (Lepidoptera-Gelechiidae) in Cotton
}

\author{
Yogesh Patel*
}

\author{
Jawharlal Nehru Agricultural University, College of Agriculture \\ Ganj-Basoda, Distt. Vidisha-464221 M.P. India \\ *Corresponding author
}

\section{Ke y w o r d s \\ Cotton, \\ Pectinophora gossypiella, Pink bollworm, Weather, population}

\section{Article Info}

Accepted:

12 March 2020

Available Online:

10 April 2020

\section{A B S T R A C T}

To study the Effect of Weather parameter on the Population of Pink Bollworm, Pectinophora gossypiella (Saunders) (Lepidoptera -Gelechiidae) in Cotton variety JK-4 were studied consecutive two cropping seasons of Kharip. The Pink bollworm, Pectinophora gossyipiella larvae was first recorded during the $39^{\text {th }}$ SMW i.e. last week of September and remained active up to $3^{\text {rd }}$ SMW i.e. IIIrd week of January, After that population showed increasing trend and attained peak during 51st SMW i.e. third week of December. The weather condition prevailed during this week viz. maximum temperature, minimum temperature, morning relative humidity, evening relative humidity, sunshine hours and wind velocity were $29.65^{\circ} \mathrm{C}, 8.74{ }^{\circ} \mathrm{C}, 82.39 \%, 40.14 \%, 7.67$ hours per day and $2.86 \mathrm{kmph}$, respectively. Further, The PBW population had a significant negative correlation with maximum temperature, minimum temperature, wind velocity, rainfall and rainy days. The multiple regression computed involving combined effect of maximum temperature $\left(\mathrm{X}_{1}\right)$, minimum temperature $\left(\mathrm{X}_{2}\right)$, morning relative humidity $\left(\mathrm{X}_{3}\right)$, evening relative humidity $\left(\mathrm{X}_{4}\right)$, sunshine hours $\left(\mathrm{X}_{5}\right)$, wind velocity $\left(\mathrm{X}_{6}\right)$, rainfall $\left(\mathrm{X}_{7}\right)$ and rainy day $\left(\mathrm{X}_{8}\right)$ was $\mathrm{Y}=116.155-2.591 \mathrm{X}_{1}+0.078 \mathrm{X}_{2}+0.344 \mathrm{X}_{3}-0.161 \mathrm{X}_{4}-2.769 \mathrm{X}_{5}-8.391 \mathrm{X}_{6}-0.191 \mathrm{X}_{7}+$ $10.789 \mathrm{X}_{8}\left(\mathrm{R}^{2}=0.899\right)$. The Path coefficient analysis revealed that morning relative humidity had positive and high direct effect on population of PBW, followed by wind velocity, maximum temperature and rainy days respectively.

\section{Introduction}

Cotton (Gossypium hirsutum Linnaeus) "White Gold" is one of the most important fiber, cash crops in India and plays a dominant role in agricultural economy of the country. India ranks first in the world in area and third in production (Anonymous 2002). Among various cardinal factors responsible for poor yield of cotton in India, the damage caused by large number of insect pests during different stages of crop growth are of prime importance.

Rathod and Baporda (2006) have been estimated that about 20 to 25 percent yield losses were encountered due to the damage caused by insect pest. Dhawan, (2001) 
recorded 162 insect species on cotton crop in India, of these, Pink Bollworm (PBW), Pectinophora gossypiella (Saunders) (Lepidoptera-Gelechiidae) is one of the most serious pest and is considered to be the major limiting factor in the successful cultivation of crop. The weather parameters play an important role both in the biology and control of the pest. In view of this, an investigation was conducted over two conductive year to study the effect of weather parameter on pink bollworm, Pectinophora gossyipiells (PBW) larvae.

\section{Materials and Methods}

The population dynamics of $P$. gossyipiells in relation to environmental factors was assessed at the Jawharlal Nehru Krishi Vishwa Vidhyalaya, Cotton Research Station, Khandwa M.P. during kharif seasons. The Cotton, Hirsutum variety JK-4 was sown in observation plot of 4000 sq. m under rain fed condition in black cotton soil during the last week of June in both the year of studied. All the normal agronomical practices recommended for the region were followed for raising the crop. No plant protection measure was taken throughout the crop season. The regular observations on the population dynamics of $P$. gossyipiells was made at weekly interval by randomly selected 25 plants from first appearance of pest until its cessation. At the same time, observations on meteorological parameters viz. minimum and maximum temperature, morning and evening percent relative humidity, total rainfall per week, total rainy days per week, wind velocity (kmph) and sunshine hours per days were recorded daily. Standard meteorological Week (SMW) average of all the data collected for the pest, predator and weather parameters were calculated before statistical analysis. The data thus, collected were computed and subjected to statistical analysis (Panse and Sukhatme, 1985). All the possible correlations, multiple regression and path analysis among the environmental factors were worked out.

\section{Results and Discussion}

\section{Population dynamics of PBW}

The data of surveillance of pest presented in (Fig. 1) indicated that the pink bollworm Pectinophora gossyipiells larvae, was first appear in the 39th ${ }^{\text {th }}$ SMW i.e. fifth week of September and remained active till 3rd SMW ( $3^{\text {rd }}$ week of January). The peak population was observed (19.33 larvae / 20 bolls ) during 51st SMW i.e. third week of December. The weather condition prevailed during this week. viz. maximum temperature, minimum temperature, morning relative humidity, evening relative humidity, sunshine hours and wind velocity were $29.65^{\circ} \mathrm{C}, 8.74^{\circ} \mathrm{C}, 82.39 \%$, 40.14\%, 7.67 hours per day and $2.86 \mathrm{kmph}$ respectively. The present finding clearly indicated that the pest activity started from last week of September and remained active upto January but peak period was attained during November- December. These finding are in accordance with those reported by Kaushik et al., (1969).

\section{Simple correlation of PBW}

The perusal of data (Table 1) on simple correlation studies between population of PBW and weather factors revealed that the PBW population had a significant negative correlation with $\max$ tem( $\mathrm{R}=-0.665)$, min tem $(\mathrm{R}=-0.736)$ wind velocity $(\mathrm{R}=-0.548)$, Rainfall $(\mathrm{R}=-0.613)$ and Rainey Days $(\mathrm{R}=-$ 0.998). After 51st SMW there was a decrease in PBW population. It was estimated that every unit increase of max. tem, min tem, wind velocity, rainfall, Rainey days there is decrease in population of PBW is 2.556, $1.009,6.78,0.304$ and 9.48. The weather condition prevailed during 51st SMW i.e. 
third week of Dec. viz. maximum temperature, minimum temperature, morning relative humidity, evening relative humidity, sunshine hours and wind velocity were $29.65^{\circ} \mathrm{C}, \quad 8.74^{\circ} \mathrm{C}, \quad 82.39 \%, \quad 40.14 \%, 7.67$ hours per day and $2.86 \mathrm{kmph}$ respectively. . Significantly negative correlation of PBW population with temperature was also observed by Gupta et al., (1996) Chaudhari, et al., (1999) and Mohapatra, et al., (2004). Chaudhari, et al., (1999) also reported that bollworm activity was negatively influenced by rainfall, wind speed, minimum temperature. However Bishnoi, et al., (1996) observed a significant relationship between the buildup of $P$. gossypiella and the mean temperature.

\section{Multiple regression analysis}

The multiple regression computed with eight parameters i.e. maximum temperature $\left(\mathrm{X}_{1}\right)$, minimum temperature $\left(\mathrm{X}_{2}\right)$, morning relative humidity $\left(\mathrm{X}_{3}\right)$, evening relative humidity $\left(\mathrm{X}_{4}\right)$, sunshine hours $\left(\mathrm{X}_{5}\right)$, wind velocity $\left(\mathrm{X}_{6}\right)$, rainfall $\left(\mathrm{X}_{7}\right)$ and rainy day $\left(\mathrm{X}_{8}\right)$ as independent variables and Pink bollworm population as dependent variables was as follows.

$\mathrm{Y}=116.155-2.591 \mathrm{X}_{1}+0.078 \mathrm{X}_{2}+0.344 \mathrm{X}_{3^{-}}$

$0.161 \mathrm{X}_{4}-2.769 \mathrm{X}_{5}-8.391 \mathrm{X}_{6}-0.191 \mathrm{X}_{7}+10.789 \mathrm{X}_{8}$

$\left(\mathrm{R}^{2}=0.899\right)$

The multiple coefficient value between the pink bollworm population and group of variable clearly indicated that $89.90 \%$ change in PBW population were affected by maximum temperature, minimum temperature, morning relative humidity, evening relative humidity, sunshine hours, wind velocity, rainfall and rainy day (Fig. 2).

Table.1 Simple correlation (r) and regression (Y) of pink bollworms, P. gossypiella larvae population with weather factors

\begin{tabular}{|c|c|c|c|c|}
\hline $\begin{array}{l}\text { S. } \\
\text { No. }\end{array}$ & Character & $\begin{array}{l}\text { First } \\
\text { Year }\end{array}$ & $\begin{array}{l}\text { Second } \\
\text { year }\end{array}$ & Pooled of two year \\
\hline 1 & $\mathrm{~T} \mathrm{MX}\left({ }^{\circ} \mathrm{C}\right)$ & $\mathrm{r}=-0.324$ & $\begin{array}{l}\mathrm{r}=0.828 * * \\
\mathrm{Y}=116.162-3.331 \mathrm{X}\end{array}$ & $\begin{array}{l}r=-0.665 * * \\
Y=90.789-2.556 X\end{array}$ \\
\hline 2 & $\mathrm{~T} \mathrm{MN}\left({ }^{\circ} \mathrm{C}\right)$ & $\begin{array}{l}r=-0.543 * \\
Y=17.827-0.659\end{array}$ & $\begin{array}{l}\mathrm{r}=-0.830 * * \\
\mathrm{Y}=27.541-1.26 \mathrm{X}\end{array}$ & $\begin{array}{l}\mathrm{r}=-0.736 * * \\
\mathrm{Y}=23.558-1.009 \mathrm{X}\end{array}$ \\
\hline 3 & RHM (\%) & $\mathrm{r}=0.316$ & $\begin{array}{l}r=0.542 * \\
Y=-65.07+0.939 X\end{array}$ & $r=0.460$ \\
\hline 4 & RHE (\%) & $\mathrm{r}=-0.190$ & $\mathrm{r}=-0.055$ & $\mathrm{r}=-0.119$ \\
\hline 5 & SSH (hpd) & $\mathrm{r}=-0.329$ & $\mathrm{r}=-0.263$ & $\mathrm{r}=-0.375$ \\
\hline 6 & $\begin{array}{l}\text { WV } \\
\text { (kmph) }\end{array}$ & $\mathrm{r}=-0.402$ & $\begin{array}{l}\mathrm{r}=-0.492 * \\
=26.032-5.329 \mathrm{X}\end{array}$ & $\begin{array}{l}r=-0.548 * \\
Y=29.79-6.78 X\end{array}$ \\
\hline 7 & $\mathrm{RF}(\mathrm{mm})$ & $\begin{array}{l}\mathrm{r}=-0.484 * \\
\mathrm{Y}=9.116-0.212 \mathrm{X}\end{array}$ & $\mathrm{r}=-0.316$ & $\begin{array}{l}\mathrm{r}=-0.613 * * \\
\mathrm{Y}=10.024-0.304 \mathrm{X}\end{array}$ \\
\hline 8 & $\mathrm{RD}(\mathrm{dpw})$ & $\begin{array}{l}\mathrm{r}=0.447^{*} \\
\mathrm{Y}=9.295-4.925 \mathrm{X}\end{array}$ & $\mathrm{r}=-0.410$ & $\begin{array}{l}r=-0.998 * * \\
Y=10.759-9.489 X\end{array}$ \\
\hline
\end{tabular}

$* \& * *$ Showed significant at $5 \% \& 1 \%$ level of significance respectively 
Table.2 Path coefficient analysis of PBW population on cotton

\begin{tabular}{|l|c|c|c|c|c|c|c|c|c|}
\hline & $\begin{array}{c}\text { T MX } \\
\left({ }^{\circ} \mathrm{C}\right)\end{array}$ & $\begin{array}{c}\mathrm{T} \text { MN } \\
\left({ }^{\circ} \mathrm{C}\right)\end{array}$ & $\begin{array}{c}\text { RHM } \\
(\%)\end{array}$ & $\begin{array}{c}\text { RHE } \\
(\%)\end{array}$ & $\begin{array}{c}\text { SSH } \\
(\mathrm{hpd})\end{array}$ & $\begin{array}{c}\text { WV } \\
(\mathrm{kmph})\end{array}$ & $\begin{array}{c}\text { RF } \\
(\mathrm{mm})\end{array}$ & $\begin{array}{c}\text { RD } \\
(\mathrm{dpw})\end{array}$ & $\begin{array}{c}\text { Correlation } \\
\text { Coefficient }\end{array}$ \\
\hline T MX & $\mathbf{0 . 4 2 8 3}$ & -0.6182 & -0.0010 & -0.0225 & -0.1954 & 0.2307 & 0.0121 & -0.0101 & -0.1761 \\
\hline T MN & 0.2695 & $\mathbf{- 0 . 9 8 2 4}$ & -0.0076 & -0.1963 & -0.0843 & 0.3932 & -0.0986 & 0.0235 & $-0.6830^{* *}$ \\
\hline RHM & -0.0007 & 0.0123 & $\mathbf{0 . 6 0 4 7}$ & -0.2575 & -0.0290 & -0.0568 & -0.0538 & 0.0254 & 0.2446 \\
\hline RHE & 0.0177 & -0.3540 & 0.2859 & $\mathbf{- 0 . 5 4 4 8}$ & 0.0310 & 0.2483 & -0.0829 & 0.0283 & $-0.3707 *$ \\
\hline SSH & 0.3359 & -0.3327 & 0.0704 & 0.0678 & $\mathbf{- 0 . 2 4 9 0}$ & 0.0988 & 0.0665 & -0.0221 & 0.0355 \\
\hline WV & 0.1961 & -0.7669 & -0.0681 & -0.2685 & -0.0488 & $\mathbf{0 . 5 0 3 8}$ & -0.0886 & 0.0122 & $-0.5288^{* *}$ \\
\hline RF & -0.0280 & -0.5239 & -0.1760 & -0.2443 & 0.0895 & 0.2414 & $-\mathbf{0 . 1 8 4 9}$ & 0.0501 & $-0.4240 *$ \\
\hline RD & -0.0629 & -0.3367 & 0.2238 & -0.2241 & 0.0801 & 0.0898 & -0.1349 & $\mathbf{0 . 0 6 8 7}$ & -0.2960 \\
\hline
\end{tabular}

Residual $=0.5212, * \& * *$ Showed significant at $5 \% \& 1 \%$ level of significance respectively, The bold figures denote the direct effect of different factors on population of pest

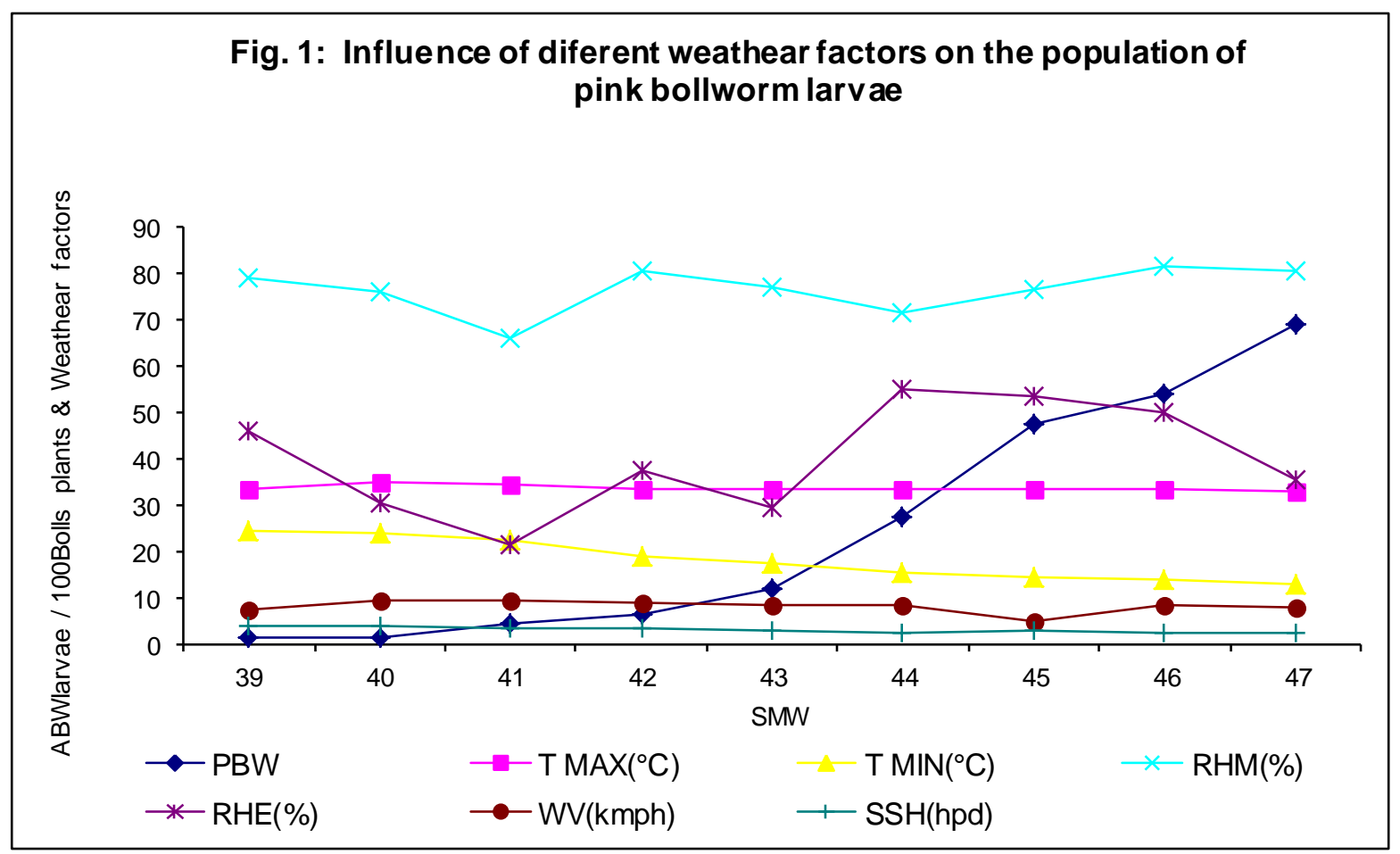

Fig.1 Influence of different weather factors on the popu;ation of pink bollworm larvae 


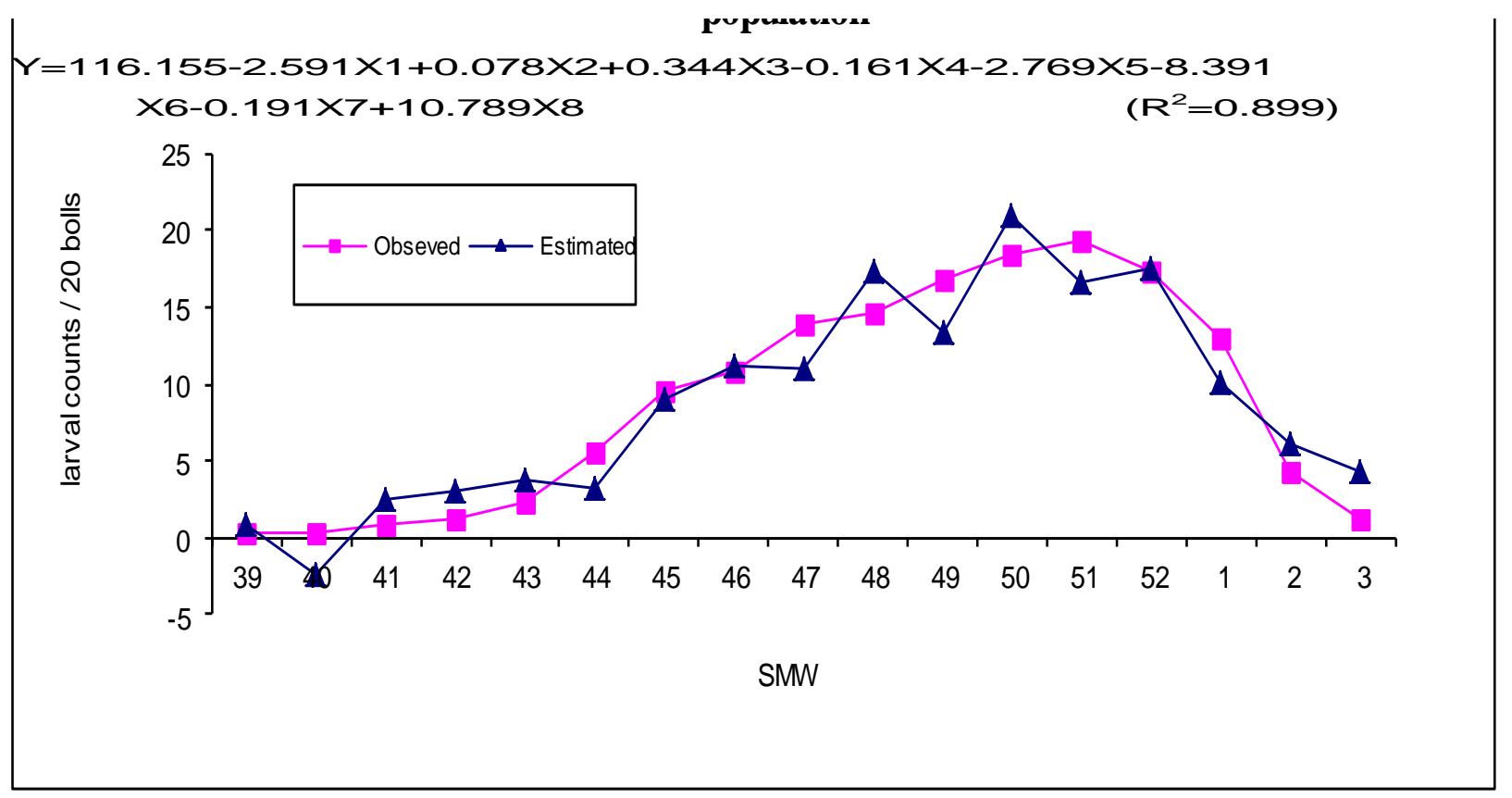

Fig.2 Multiple regression of weather factors on pink bollworm larva population

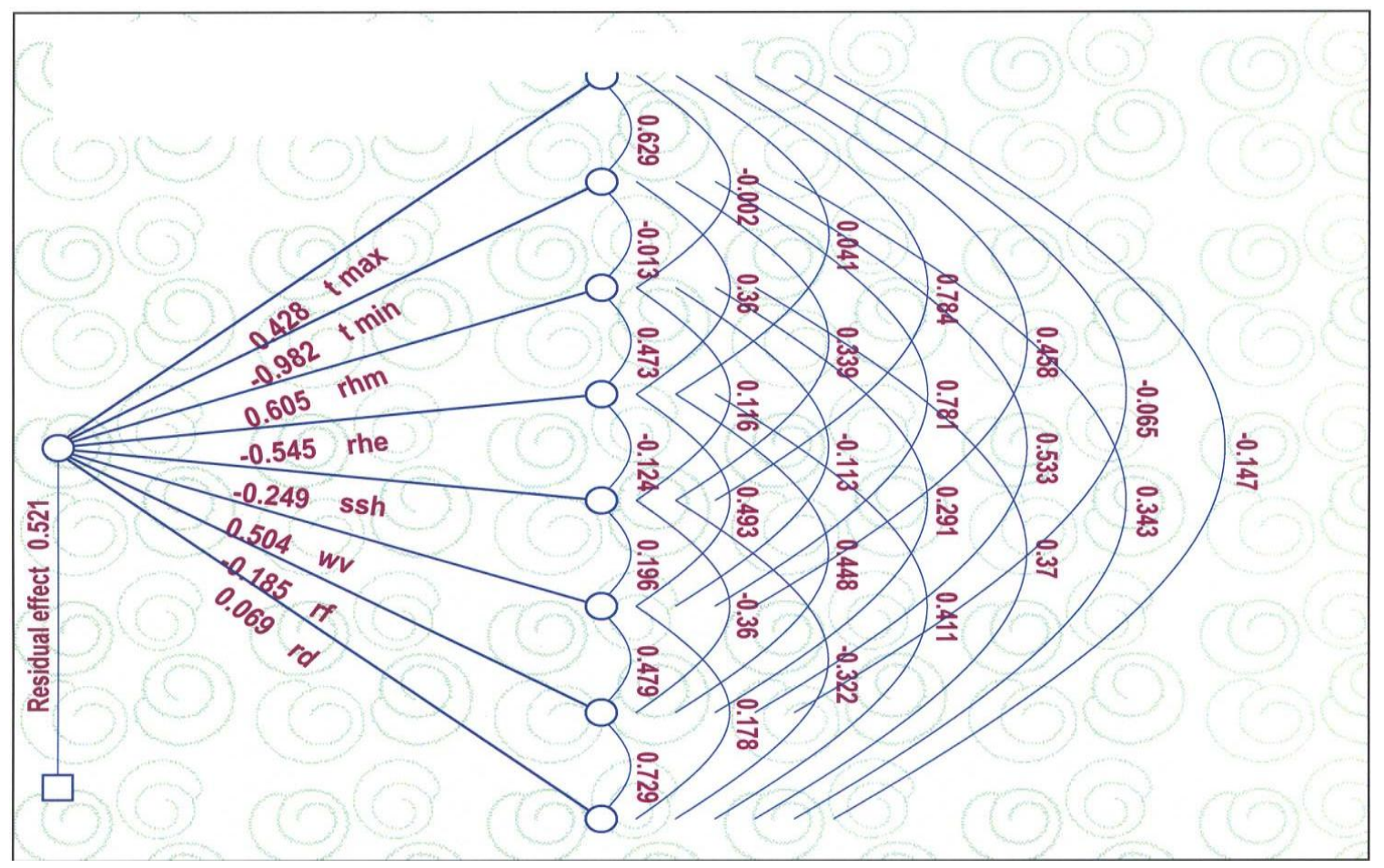

Fig.3 Phonotypical path diagram showing influence of weather factors on the population of Pink bollworms larvae

\section{Path coefficient analysis}

Path coefficient analysis of various weather parameters with PBW has been presented in table 2 and figure 3. The weather factor exhibited significant positive correlations with PBW population were minimum temperature ($0.6830)$, evening relative humidity $(-0.3707)$, 
wind velocity (-0.5288) and rainfall (-0.4240) respectively.

The data revealed that morning relative humidity had positive and high direct effect (0.6047) followed by wind velocity (0.5038), maximum temperature (0.4283) and rainy days (0.0687) respectively.

Path coefficient effect revealed that the positive indirect effect of high magnitude of morning relative humidity was obtained via rainy days (0.0254) and minimum temperature $(0.0123)$ respectively.

The positive indirect effect of wind velocity was obtained via maximum temperature $(0.1961)$ and rainy days (0.0122). Positive indirect effect of maximum temperature was obtained via wind velocity $(0.2307)$ and rainfall $(0.0121)$.

Path coefficient effect revealed that the positive indirect effect of rainy days was recorded via morning relative humidity $(0.2238)$, wind velocity (0.0898) and sun shine hours (0.0801).

On the bases of the present investigation, It can be concluded that weather parameter i. e., minimum temperature, evening relative humidity, wind velocity and rainfall play vital role in suppression of PBW population and it can be used as effective tool in the sustainable management of $P B W$ population in the cotton ecosystem.

\section{References}

Anonymous (2002). All India Coordinated cotton improvement project annual report, Khandwa. pp: 96
Bishnoi, O.P., Mohan, Singh, Rao., Vum, Ram, Niwas,; Sharma. Singh, P.D. and Niwas, R (1996). Population dynamics of cotton pest in relation to weather parameters. Indian journal of Entomology. 58(2):103107

Chaudhari, G. B., Bharpoda, T.M., Patel, J.J., Patel, K.I., Patel, J.R. (1999) Effect of weather on activity of cotton bollworms in middle Gujarat. Journal of Agrometeorology 1(2): 137-142

Dhawan, A. K. (2001) Impact of some new insecticides on natural enemy complex of cotton ecosystem. Pestology Vol XXIV No 5, 8-15

Gomez, K.A. and Gomez, A.A. (1984). Statistical Procedures for Agricultural Research (IInd edition), An International Rice Research Institute, A wiba International publication, John willey and sons, New york . pp 680

Gupta, M.P, Gupta, D.P., Shrivastava, K.K. (1996). Population Dynamics of cotton bollworm in Madhya Prdesh. Annals of Entomology. 14 (1): 66-66

Kaushik, U.K., Rathore, V.S. and Sood, N.K. (1969). Incidence of bollworms and losses caused to cotton in Madhya Pradesh. Indian J. Ent., 31(2):175-177.

Mahapatro, G.K. and Gupta, G.P. (2001). An approach for ascending the impact of abiotic factors on damage profile of bollworm in cotton. Agro ecosystem. $J$. cotton Res. Dev. 15(1), 121-123

Rathod, R.R. and Bapodra, J.G. (2002) Relative toxicity of various insecticides to coccinellid predators in cotton. Indian Journal of Plant Protection 30(1): 29-31

Panse, V.G. and Sukhatme, P.V. (1985). Statistical methods for Agricultural Research. ICAR, New Delhi.

\section{How to cite this article:}

Yogesh Patel. 2020. Effect of Weather Parameter on the Population of Pink Bollworm, Pectinophora gossypiella (Saunders) (Lepidoptera-Gelechiidae) in Cotton. Int.J.Curr.Microbiol.App.Sci. 9(04): 1476-1481. doi: https://doi.org/10.20546/ijcmas.2020.904.173 